\title{
Recovery of Alum from Surabaya Water Treatment Sludge using Electrolysis with Carbon-Silver Electrodes
}

\author{
Rizkiy Amaliyah Barakwan, Tyta Try Hardina1, Yulinah Trihadiningrum", \\ Arseto Yekti Bagastyo' \\ 1 Department of Environmental Engineering, Faculty of Civil, Environmental, and Geo-Engineering \\ Institut Teknologi Sepuluh Nopember, Kampus ITS Sukolilo, Surabaya, 60111, Indonesia \\ * Corresponding author's e-mail: trihadiningrum@gmail.com
}

\begin{abstract}
Untreated alum sludge from Surabaya water treatment plant (WTP), which contained high concentration of alum was directly discharged into Surabaya River. It might cause problems because of the accumulation of aluminum in the lower part of the river. Alum could be recovered from the drinking water sludge using the electrolysis method. Aims of this study were to determine the optimum $\mathrm{pH}$ and electrical current for electrolysis using carbon-silver electrodes to recover aluminum coagulant from the sludge, and to determine the amount of the recovered alum. The sludge was acidified prior to electrolysis. Acidification was done by adding sulfuric acid at $\mathrm{pH} 3$ and 4. Polarization test was conducted at 100,200, and $300 \mathrm{~mA}$, in order to determine the optimum electrical current. The electrolysis was performed in one compartment batch recirculation reactor, using silver as cathode and carbon as anode for 10 hours. Values of $\mathrm{pH}$ were measured every hour. The precipitated matter in the cathode was weighed, and analysed by means of Inductively Coupled Plasma. The optimum conditions of the electrolysis were achieved at initial pH 3 and electrical current $300 \mathrm{~mA}$. The electrolysis resulted in the highest precipitate of $2.6112 \mathrm{~g}$ in the cathode.
\end{abstract}

Keywords: alum, drinking water, electrolysis, recovery, sludge

\section{INTRODUCTION}

Clean water, as one of the basic needs of urban population, is provided by municipal water supply companies, with post raw water treatment sludge as residue. The rapid population growth in large cities in Indonesia, especially in Surabaya, has caused the water demand to increase. Therefore, the drinking water sludge, which contains high amounts of aluminum would increase too [Selintung, 2012]. The high aluminum content in the drinking water sludge results from the use of aluminum sulfate $\left(\mathrm{Al}_{2}\left(\mathrm{SO}_{4}\right)_{3}\right)$ as coagulant to reduce turbidity and total suspended solids (TSS) in the raw water [Ahmad et al., 2016]. As an example, the aluminum concentration in Code River, Yogyakarta was $128.43 \mathrm{mg} / \mathrm{L}$ [Hanim et al., 2007]. Dassanayake [Dassanayake et al., 2015] further stated that the total aluminum concentration in the accelerator unit was $4794 \mathrm{mg} / \mathrm{L}$. The amount of sludge which was discharged into Surabaya River by Surya Sembada Water Treatment Plant (WTP) was $626 \mathrm{~m}^{3} / \mathrm{day}$, with the aluminum concentration of $250 \mathrm{mg} / \mathrm{L}$ [Primadipta and Titah, 2017]. According to the Government Regulation of the Republic of Indonesia No. 82/2001, the maximum allowable aluminum concentration for Class A water is $0.2 \mathrm{mg} / \mathrm{L}$.

A direct discharge of WTP sludge into a river might cause metal pollution, such as aluminum, lead, chromium, copper, and cadmium to occur [Georgantas and Grigoropoulou, 2005]. Aluminum could be accumulated in the sediment of the lower river part [7], in aquatic biota and humans via food chain [Ippolito et al., 2011]. The bioaccumulated aluminum is potentially toxic to the growing aquatic biota [Cheng et al., 2012]. Furthermore, it may be toxic to humans, resulting, 
i.a. in central nervous system failure, dementia, memory loss, lethargy, and severe trembling [Ahmad et al., 2016].

Aluminum recovery from the WTP sludge can be done with a combination of acidification and electrolysis processes. Acidification is aimed at dissolving the aluminum in the sludge [Cheng et al., 2012]. The next stage is electrolysis, which can separate the dissolved aluminum. This last stage has an advantage for not requiring the addition of chemical substances and producing precipitate with high aluminum purity [Huang et al., 2007]. The aims of this study were to determine the optimum $\mathrm{pH}$ and electrical current for electrolysis using carbon-silver electrodes to recover the aluminum coagulant from the sludge, and to determine the amount of the recovered alum.

\section{MATERIALS AND METHODS}

\section{Alum sludge sampling and characterization}

The alum sludge samples were collected from clearator drains of the Surabaya WTP in February 2018 . The sludge was dried at $105^{\circ} \mathrm{C}$ for 24 hours, and characterized according to moisture, alkalinity, $\mathrm{pH}$, chemical oxygen demand (COD), biochemical oxygen demand (BOD), volatile solids (VS), total dissolved solids (TDS), sludge volume index (SVI), and metal ( $\mathrm{Al}, \mathrm{Fe}, \mathrm{Cu}, \mathrm{Cr}$, and $\mathrm{Pb}$ ) concentrations. The procedures followed the Standard Methods for Water and Wastewater Treatment Analysis [APHA, 2012].

\section{Acidification}

Two hundred g of dried alum sludge was added with distilled water up to $1000 \mathrm{~mL}$. Then, sulfuric acid was added for acidification in order to achieve solutions with the $\mathrm{pH}$ of 3 and 4 . The acidified sludge solution was homogenized using magnetic stirrer with $800 \mathrm{rpm}$ for 120 minutes. Centrifugation was applied to separate the solid fraction from the solution, which contained metal ions. The solution was used as electrolyte during the electrolysis.

\section{Polarization test}

The polarization test was carried out to determine electric current and potential ranges in the electrolysis. In this study, three current variations from polarization curve would be used.
Cell potential and current density for aluminum coagulant recovery using electrolysis could be determined from the polarization curve.

The previous studies showed that the cell potential was around 0,2 V [Widayatno et al., 2016]. In this study, polarization test was conducted at $\mathrm{pH} 3$ with cell potential ranges of $0.0-6.0 \mathrm{~V}$ and $6.0-10.0 \mathrm{~V}$, by putting significant TDS value decrease into consideration. The increase of cell potential values was adjusted every 3 minutes, and the TDS as well as current were measured. The polarization test data were used for preparing a polarization curve using TDS data and the cell potential value within $0.0-6.0 \mathrm{~V}$ and $6.0-10.0 \mathrm{~V}$ ranges. Electric current at the cell potential value, which showed a significant TDS decrease, was selected to run the electrolysis.

\section{Electrolysis process}

A laboratory scale batch recirculation reactor with one compartment (Figure 1a) was used, following Selvakumar et al. [2016]. The reactor was made from acrylic with a dimension of $5 \mathrm{~cm}$ (l) $\times 2 \mathrm{~cm} \mathrm{(w)} \times 20 \mathrm{~cm}(\mathrm{~h})$. Silver was used for cathode for its highest conductivity, compared to other metals. The high conductivity, softness (low hardness), and high resistance to oxidation make silver an excellent choice for contact materials. Carbon was selected as anode for its corrosion resistant, high electronic conductivity, and its abundant and low cost reasons. The electrodes were of plate forms with a dimension of $2 \mathrm{~cm}(\mathrm{l}) \times 5 \mathrm{~cm}(\mathrm{w})$. The thickness of carbon anode and silver cathode was $0.1 \mathrm{~cm}$ and $0.5 \mathrm{~cm}$, respectively. The distance between electrodes was $1 \mathrm{~cm}$. Configuration of the reactor is shown in Figure 1b. The electric current source was DC Power Supply. A peristaltic pump was used for flowing the electrolyte from $1 \mathrm{~L}$ feed tank to the cell with a discharge rate of $5 \mathrm{~mL} / \mathrm{s}$.

The initial $\mathrm{pH}$ values of the electrolysis were adjusted to 3 and 4, following Sengupta [2002] and Bahena et al. [2002]. The electric current values were obtained from the results of polarization tests. The operation time of electrolysis was 10 hours. TDS and $\mathrm{pH}$ were measured every hour. The recovered deposited matter at the cathode was weighed, and then soaked with $50 \mathrm{~mL}$ nitric acid [Ahmad, 2011]. The dissolved aluminum and metal impurities were measured using Inductively Coupled Plasma (ICP) type Agilent Technologies series 700 ICP-OES. The results were used to determine the amount and purity of aluminum coagulant from the electrolysis. 
a)

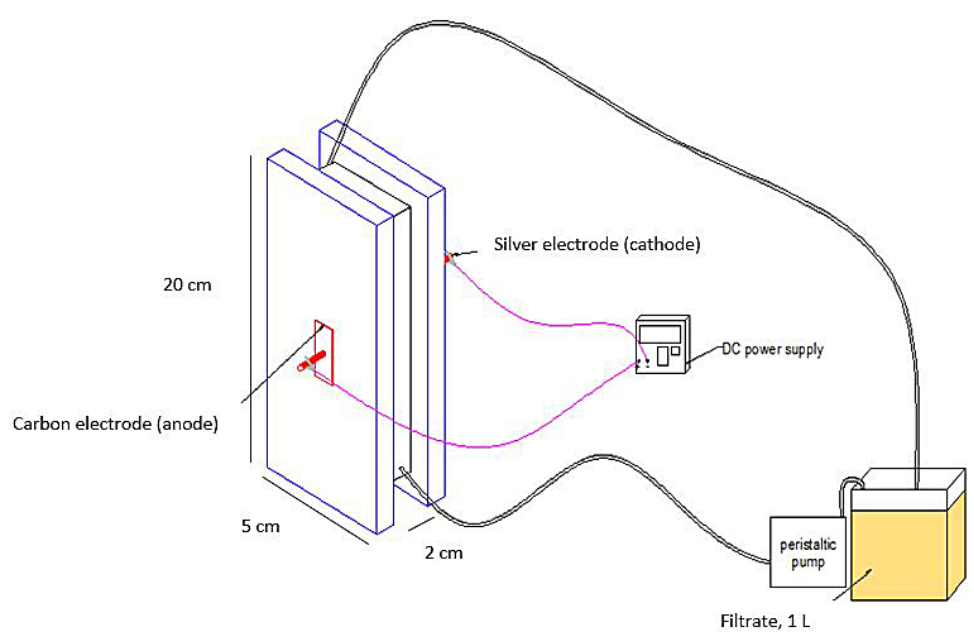

b)

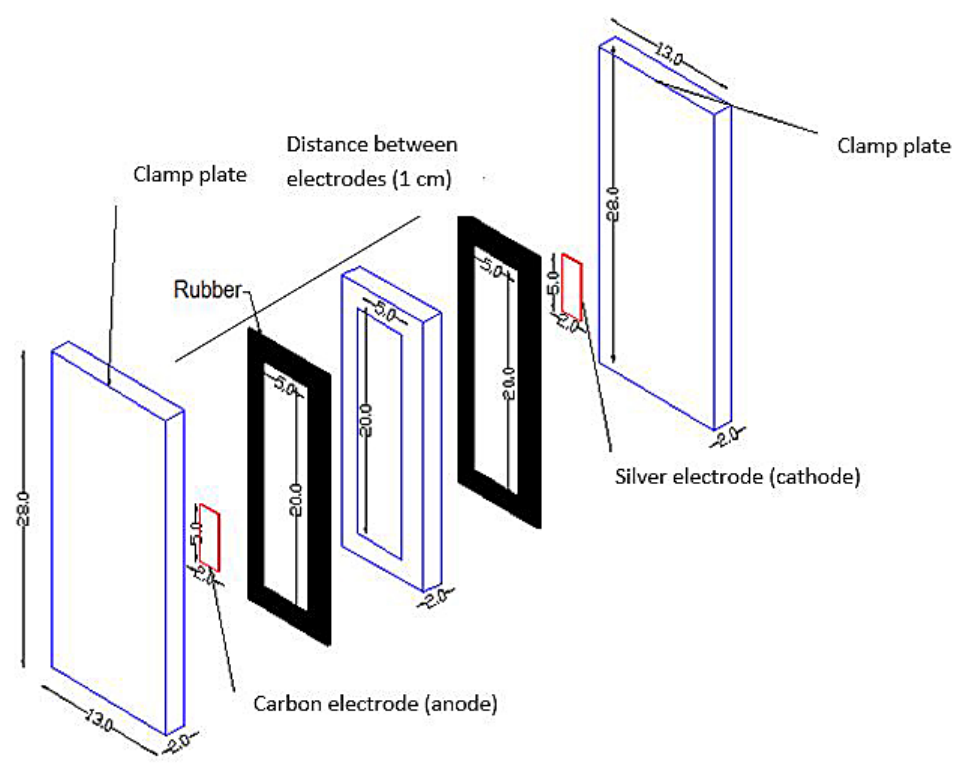

Figure 1. (a) Electrolysis reactor design, (b) Electrolysis reactor configuration

\section{RESULTS AND DISCUSSIONS}

\section{Alum sludge characteristicss}

The alum sludge samples were collected from clearator drains in Surabaya WTP. Metals and organics were the main components of the sludge. The alum sludge characteristics were applied as references for proper treatment methods.

As shown in Table 1, the largest metal concentration in the sludge corresponded to aluminum $(1194 \mathrm{mg} / \mathrm{L})$. This high concentration of the aluminum creates a potential for recovery. According to National Pollutant Discharge Elimination System (NPDES), this concentration exceeded the daily maximum limitation of $1,5-10 \mathrm{mg} / \mathrm{L}$ [EPA, 2011]. Other metals in the sludge were Fe $(515 \mathrm{mg} / \mathrm{L}), \mathrm{Cu}(0.559 \mathrm{mg} / \mathrm{L})$, and $\mathrm{Cr}(0.217 \mathrm{mg} / \mathrm{L})$. Iron was present in considerably high concentration. The source of iron was the high concentration of suspended solids in the sludge $(12,511 \mathrm{mg} / \mathrm{L})$, which was mainly soil particulate in the raw water. Copper and chromium in the sludge were originated from improperly treated industrial waste water which was commonly discharged into Surabaya river.

The BOD and COD concentrations of the sludge were $936.8 \mathrm{mg} / \mathrm{L}$ and 9,000 mg/L, respectively. These concentrations exceeded the effluent standards of the State Ministry for The Environment Decree of Republic Indonesia No. 5/2014, which were $50 \mathrm{mg} / \mathrm{L}$ and $100 \mathrm{mg} / \mathrm{L}$, respectively. The BOD/COD ratio of 0.1 indicated that the organic content in alum sludge was non-biodegradable [Dahou, 2017]. Such a high organic content originated from industrial and domestic wastewater sources. 
Table 1. Alum sludge characteristics

\begin{tabular}{|l|c|c|}
\hline \multicolumn{1}{|c|}{ Parameters } & Concentration & Unit \\
\hline Water content & 98.4 & $\%$ \\
\hline Alkalinity & 75 & $\mathrm{mg} / \mathrm{L} \mathrm{HCO}_{3}{ }^{-}$ \\
\hline $\mathrm{pH}$ & 7.46 & - \\
\hline $\mathrm{COD}$ & 9,000 & $\mathrm{mg} / \mathrm{L}$ \\
\hline BOD $_{5}$ & 936.8 & $\mathrm{mg} / \mathrm{L}$ \\
\hline Volatile Solids & $12,816.7$ & $\mathrm{mg} / \mathrm{L}$ \\
\hline $\begin{array}{l}\text { Total Dissolved } \\
\text { Solids }\end{array}$ & 370.4 & $\mathrm{mg} / \mathrm{L}$ \\
\hline $\begin{array}{l}\text { Total Suspended } \\
\text { Solids }\end{array}$ & 12511 & $\mathrm{mg} / \mathrm{L}$ \\
\hline $\mathrm{Al}$ & 1194 & $\mathrm{mg} / \mathrm{L}$ \\
\hline $\mathrm{Fe}$ & 515 & $\mathrm{mg} / \mathrm{L}$ \\
\hline $\mathrm{Cu}$ & 0.559 & $\mathrm{mg} / \mathrm{L}$ \\
\hline $\mathrm{Cr}$ & 0.217 & $\mathrm{mg} / \mathrm{L}$ \\
\hline
\end{tabular}

\section{Polarization test}

The polarization test, which was performed at a cell potential range of $0-6 \mathrm{~V}$ at $\mathrm{pH} 3$, generated electrical current 0-500 mA. During the test, the TDS values in the electrolyte decreased from $5.3 \mathrm{~g} / \mathrm{L}$ to $1.6 \mathrm{~g} / \mathrm{L}$ at the cell potential $5.8 \mathrm{~V}$ (Figure 2). The polarization test which was carried out in the cell potential range of $6-10 \mathrm{~V}$, generated current in the range of 500-1000 mA (Figure 3). The TDS concentration decreased abruptly from 5.28 to $0.014 \mathrm{~g} / \mathrm{L}$ at cell potential $6.0-9.0 \mathrm{~V}$. A drastic decrease of TDS during the second polarization test might cause water electrolysis, which needs high energy consumption [Songa et al., 2008]. Therefore, cell potential range of $0-6 \mathrm{~V}$ with electrical current $0-500 \mathrm{~mA}$ were considered to be appropriate for performing the electrolysis of the alum sludge.

When conducted at the electrical current of 100-300 mA, electrolysis of the acidified alum sludge worked, as indicated by the appearance of gas bubbles around the cathode and anode. Both gases were formed vigorously at electrical current above $300 \mathrm{~mA}$. This might indicate that the unexpected electrolysis of water occurred. Therefore, the electrical current variations for the electrolysis in this experiment were 100, 200, and $300 \mathrm{~mA}$.

\section{Electrolysis process}

\section{pH Values}

The $\mathrm{pH}$ values of the electrolyte showed a slight decrease during the electrolysis process. At the electrical current of $100 \mathrm{~mA}$, the electrolyte with initial $\mathrm{pH} 3$ showed stable $\mathrm{pH}$ values, whereas the electrolyte with initial $\mathrm{pH} 4$ showed a decrease in $\mathrm{pH}$ from 4.01 to 3.00 (Figure 4). When performed at $200 \mathrm{~mA}$, the $\mathrm{pH}$ values of the electrolyte decreased from 3.07 to 2.52 and 4.09 to 2.65 , at initial $\mathrm{pH} 3$ and 4 , respectively (Figure 5). If the current was increased to $300 \mathrm{~mA}$, the $\mathrm{pH}$ of the solutions with the initial value of 4 tended to be relatively constant. However, the solution with initial $\mathrm{pH} 3$ decreased from 3.2 to 2.47 (Figure 6).

The slight $\mathrm{pH}$ decrease during electrolysis with electric currents 100 to $300 \mathrm{~mA}$ can be explained as follows. A simultaneous formation of $\mathrm{H}^{+}$ion from $\mathrm{H}_{2} \mathrm{O}$ occurred in the cathode (Eq. 1), and $\mathrm{H}^{+}$ion was used for the formations $\mathrm{H}_{2} \mathrm{SO}_{4}$ at the anode (Eq. 2) and $\mathrm{H}_{2}$ at the cathode (Eq.3). During the electrolysis, $\mathrm{Al}(\mathrm{OH})_{3}$ was formed in the cathode (Eq. 4) from $\mathrm{Al}^{3+}$, which was present in the acidified electrolyte. These reactions are shown in Eq. 1-4 [Chen et al., 2000]:

Reactions at anode:

$$
2 \mathrm{H}_{2} \mathrm{O} \rightarrow 4 \mathrm{H}^{+}+4 \mathrm{e}^{-}+\mathrm{O}_{2}
$$

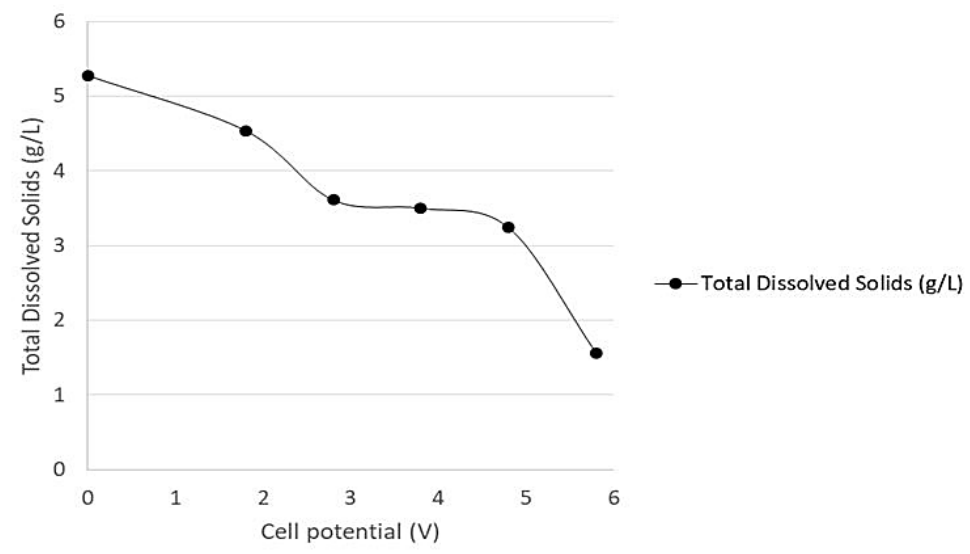

Figure 2. Influence of the cell potential to TDS values $(i=0-500 \mathrm{~mA})$ 
$\mathrm{SO}_{4}{ }^{2-}+2 \mathrm{H}^{+} \rightarrow \mathrm{H}_{2} \mathrm{SO}_{4}$

Reactions at cathode:

$2 \mathrm{H}^{+}+2 \mathrm{e}^{-} \rightarrow \mathrm{H}_{2}$

$\mathrm{Al}^{3+}+3 \mathrm{OH}^{-} \rightarrow \mathrm{Al}(\mathrm{OH})_{3}$

\section{Aluminum Deposition at Cathode}

The highest weight of deposited matter at the cathode was $2.6112 \mathrm{~g}$, which was gained in electrolysis of acidified sludge with initial $\mathrm{pH}$ of 3 at $300 \mathrm{~mA}$. The second and third weights of deposited matter were $2.329 \mathrm{~g}$ and $1.2979 \mathrm{~g}$ at initial $\mathrm{pH}$

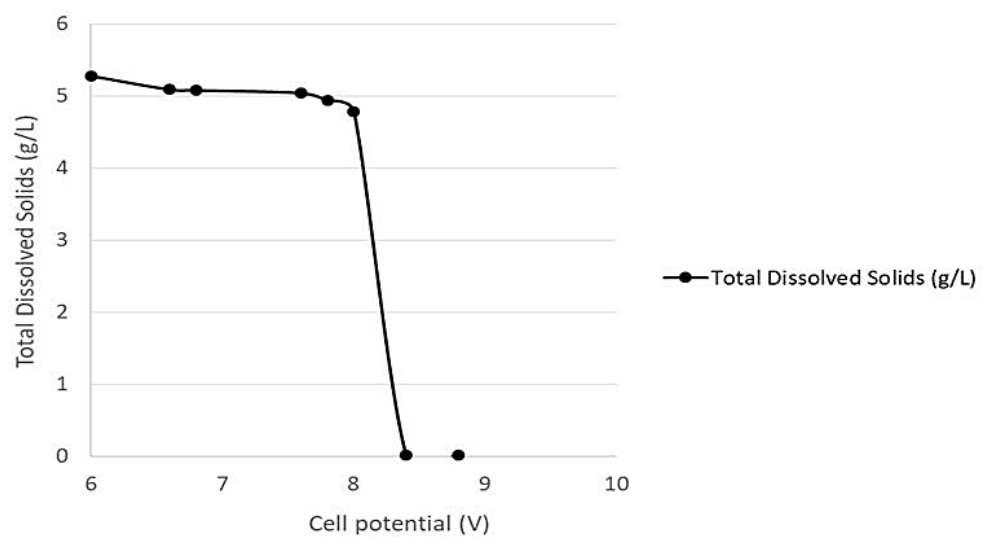

Figure 3. Influence of the cell potential to TDS values (i=500-1000 mA)

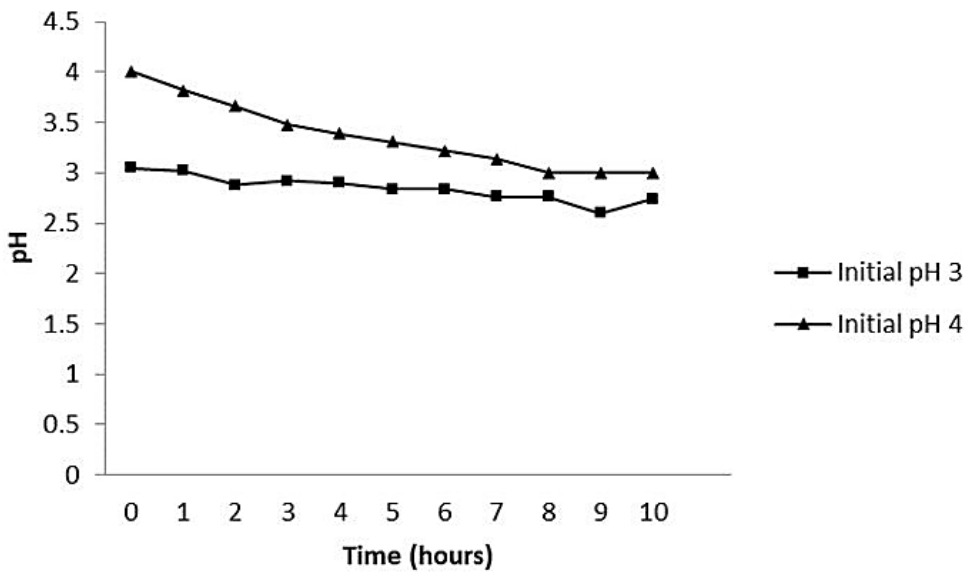

Figure 4. Comparison of $\mathrm{pH}$ values $(\mathrm{i}=100 \mathrm{~mA})$

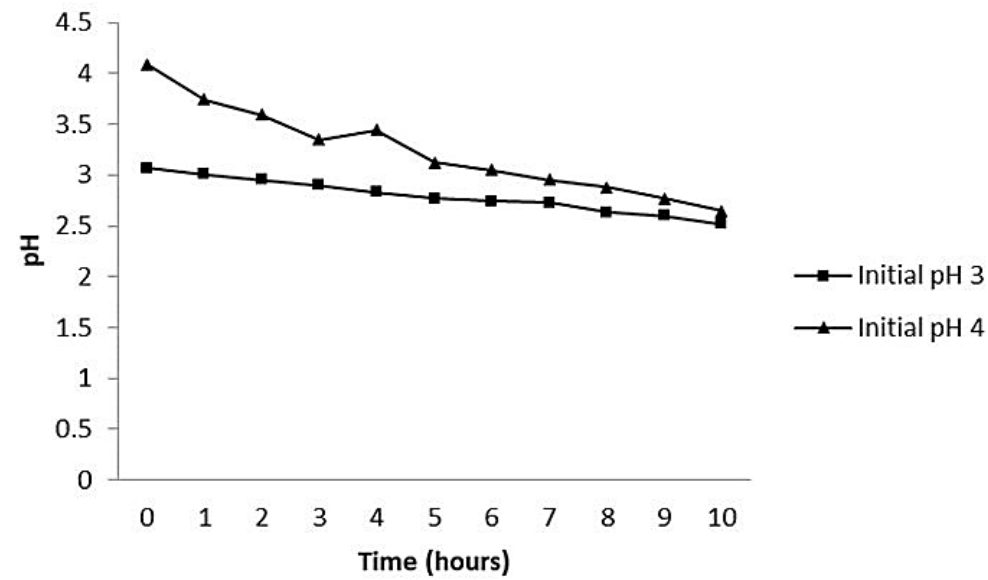

Figure 5. Comparison of $\mathrm{pH}$ values $(\mathrm{i}=200 \mathrm{~mA})$ 


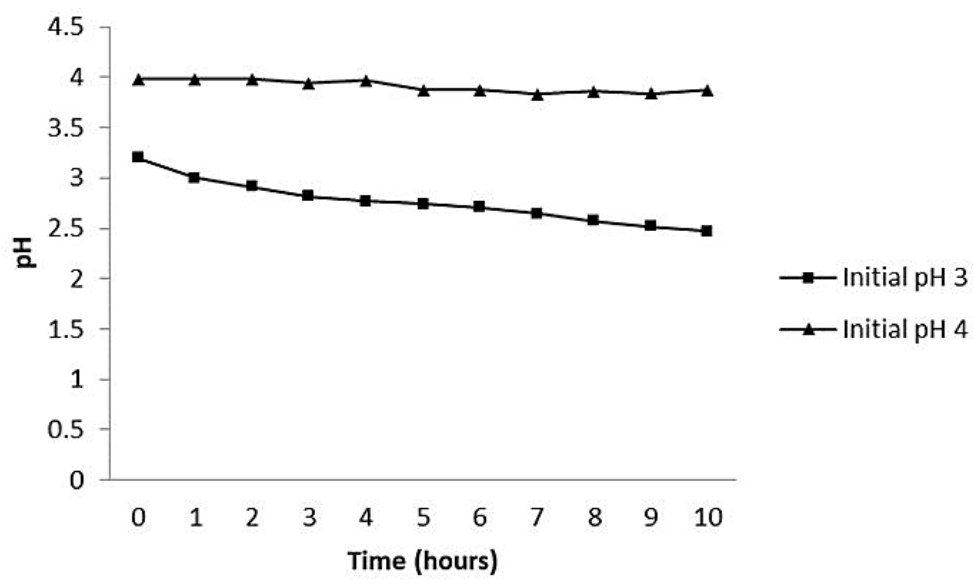

Figure 6. Comparison of $\mathrm{pH}$ values $(\mathrm{i}=300 \mathrm{~mA}$ )

4 at $300 \mathrm{~mA}$ and $200 \mathrm{~mA}$, respectively (Table 2). This met the Faraday I Law, which stated that the mass of substance in the electrode is directly proportional to the amount of electric charge in the electrolyte solution [Buddhi et al., 2006].

The percentage of aluminum recovery, as shown in Table 2 can be calculated from the deposited $\mathrm{Al}(\mathrm{OH})_{3}$ in the cathode. The aluminum concentration in recovered matter from the results of ICP measurement was calculated as well. The percentage of recovery was obtained from Eq. 5.

$$
\begin{gathered}
\% \text { alumina recovery }= \\
=\frac{\text { mass Al at cathode }(\mathrm{g})}{\text { mass Al at } \mathrm{t} 0 \mathrm{~g})} \times 100 \%
\end{gathered}
$$

Percentage of alum recovery was $26.20-28.72 \%$ in the electrolysis with initial $\mathrm{pH}$ of 3 and 4 at $300 \mathrm{~mA}$. The percentages of alum recovery also increased along with the increasing of $\mathrm{pH}$ values (Table 2). This result was in accordance with the research of Sengupta [Sengupta, 2002], which showed that the optimum alum recovery with electrolysis was at a $\mathrm{pH} 3$ to 4 . This researcher further stated that at this $\mathrm{pH}$ range, the chemical reactions were faster, and the cations more easily attached in the cathode.

The low alum recovery was most probably caused by the high COD in the alum sludge. The high organic content caused the decrease of conductivity and electron transfer between the anode and cathode [Huitle et al., 2018]. Therefore, it is

\begin{tabular}{|c|c|c|c|c|c|}
\hline Treatment & $\begin{array}{c}\text { Al concentration } \\
\text { at } \mathrm{t}_{0}(\mathrm{mg} / \mathrm{L})\end{array}$ & $\begin{array}{l}\text { Total weight of } \\
\text { Al at } t_{0}(g)\end{array}$ & $\begin{array}{l}\text { Weight of deposited } \\
\text { matter at cathode }(\mathrm{g})\end{array}$ & $\begin{array}{c}\text { Weight of alum deposit } \\
\text { at cathode }(\mathrm{g})\end{array}$ & $\begin{array}{c}\begin{array}{c}\text { Aluminum recovery } \\
(\%)\end{array} \\
\end{array}$ \\
\hline $\mathrm{pH} 3,100 \mathrm{~mA}$ & 2816.465 & 2.816 & 1.264 & 1.119 & 13.76 \\
\hline $\mathrm{pH} \mathrm{4,} 100 \mathrm{~mA}$ & 1094.200 & 1.094 & 0.792 & 0.762 & 24.12 \\
\hline $\mathrm{pH} 3,200 \mathrm{~mA}$ & 3896.900 & 3.897 & 1.065 & 1.011 & 8.98 \\
\hline $\mathrm{pH} 4,200 \mathrm{~mA}$ & 1337.180 & 1.337 & 1.298 & 1.246 & 32.24 \\
\hline $\mathrm{pH} 3,300 \mathrm{~mA}$ & 3341.665 & 3.342 & 2.611 & 2.529 & 26.20 \\
\hline $\mathrm{pH} \mathrm{4,300} \mathrm{mA}$ & 2721.600 & 2.722 & 2.329 & 2.258 & 28.72 \\
\hline
\end{tabular}

Table 2. Calculation of aluminum recovery

Table 3. Metal ion composition in deposited matter at the cathode

\begin{tabular}{|c|c|c|c|c|c|}
\hline \multirow{2}{*}{ Electrolysis condition } & \multicolumn{5}{|c|}{ Composition (\%) } \\
\cline { 2 - 6 } & $\mathrm{Al}$ & $\mathrm{Cu}$ & $\mathrm{Pb}$ & $\mathrm{Fe}$ & $\mathrm{Cr}$ \\
\hline $\mathrm{pH} \mathrm{3,100} \mathrm{mA}$ & 88.55 & 3.72 & 3.32 & 0.84 & 3.56 \\
\hline $\mathrm{pH} \mathrm{4,100} \mathrm{mA}$ & 96.21 & 1.56 & 0.41 & 0.42 & 1.37 \\
\hline $\mathrm{pH} \mathrm{3,200} \mathrm{mA}$ & 94.94 & 1.42 & 1.35 & 0.91 & 1.37 \\
\hline $\mathrm{pH} \mathrm{4,200} \mathrm{mA}$ & 95.97 & 1.77 & 0.41 & 0.44 & 1.39 \\
\hline $\mathrm{pH} \mathrm{3,300} \mathrm{mA}$ & 96.86 & 0.89 & 0.85 & 0.79 & 0.58 \\
\hline $\mathrm{pH} \mathrm{4,300} \mathrm{mA}$ & 96.95 & 1.09 & 0.61 & 0.31 & 1.01 \\
\hline
\end{tabular}


recommended that the organic contaminant to be removed before the electrolysis.

\section{Metal composition in the deposited matter}

The metal composition in the deposited matter, as shown in Table 3, was dominated by Al $(88.55-96.95 \%)$. Other metal contaminants were $\mathrm{Cu}(0.89-3.72 \%), \mathrm{Pb}(0.41-3.32 \%)$, Fe $(0.31-0.91 \%)$, and $\mathrm{Cr}(0.58-3.56 \%)$. Metal contaminants showed higher composition at initial electrolyte $\mathrm{pH}$ 3-4 and electrical current $100 \mathrm{mV}$.

These metal contaminants can be removed by applying anionic exchange membrane during the electrolysis [Varcoe et al., 2014]. Taking the deposited matter weight and the metal composition into consideration, the optimum conditions for alum recovery using electrolysis method with carbon and silver electrodes occurred at $\mathrm{pH} 3$ and electrical current $300 \mathrm{~mA}$.

\section{CONCLUSIONS}

The optimum conditions for alum recovery from acidified drinking water sludge using electrolysis with carbon-silver electrodes were obtained at initial $\mathrm{pH} 3$ and electrical current 300 $\mathrm{mA}$. The low alum recovery and the presence of heavy metal contaminants in the sludge should be considered for removal, when future electrolysis method is applied.

\section{Acknowledgments}

The authors are grateful for the financial support from the Ministry of Research and Higher Education of the Republic Indonesia with Master leading to $\mathrm{PhD}$ scholarship (PMDSU), which made this study to work out.

\section{REFERENCES}

1. Ahmad M.A. 2011. Analysis of the effect of electrical voltage to the thickness of chrome coating on steel plates with electroplating process [thesis]. Department of Mechanical Engineering, Universitas Hasanudin: Makassar. (In Indonesian)

2. Ahmad T., Ahmad K., Alam M. 2016. Sustainable management of water treatment sludge through 3 ' $R$ ' concept. Journal of Cleaner Production, 124, 1-13.

3. APHA. 2012. Standard methods for the examination of water and wastewater 22th ed. Washington, DC: American Public Health Association.
4. Bahena J.L.R., Cabrera A.R., Valdivieso A.L., and Urbina R.H. 2002. Fluoride adsorption onto $\alpha-\mathrm{A} 12 \mathrm{O} 3$ and its effect on the zeta potential at the alumina- aqueous electrolyte interface. Science Technology, 37, 1973-1987.

5. Buddhi D., Kothari R., and Sawhney R.L. 2006. An experimental study on the effect of electrolytic concentration on the rate of hydrogen production. International Journal of Green Energy, 3 (4), 381-395.

6. Chen X., Chen G., and Yue P.L. 2000. Separation of pollutants from restaurant wastewater by electrocoagulation. Sep. Purification Technologie, 19: 65-76.

7. Cheng W.P., Fu C.H., Chen P.H., and Fang Y. 2012. Dynamics of aluminum leaching from water purification sludge. Journal of Hazardous Materials, 217, 149-155.

8. Dahhou M. 2017. Drinking water sludge of the Moroccan capital: statistical analysis of its environmental aspects. Journal of Taibah University for Science, 749-758.

9. Dassanayake K.B., Jayasinghe G.Y., and Surapaneni A. 2015. A review on alum sludge with special reference to agricultural applications and future challenges. Waste Management Journal, 38, 321-335.

10. EPA(United States Environmental Protection Agency). 2011. Drinking water treatment plant residuals management technical report: EPA 820-R-11-003. United States: Environmental Protection Agency.

11. Georgantas D.A. and Grigoropoulou H.P. 2005. Phosphorus removal from synthetic and municipal wastewater using spent alum sludge. Water Science \& Technology, 52, 525-532.

12. Hanim A., Azam M., Hidayanto E., and Nuraini E. 2007. Determination of aluminum, manganese, and silicon elements in the Code River to sampling time with AANC method. Berkala Fisika, 10 (1), 25-30. (In Indonesian)

13. Huang C., Xu T., Zhang Y., Xue Y., and Chen G. 2007. Application of electrodialysis to the production of organic acids: state-of-the-art and recent developments. Journal of Membrane Science, 288: $1-12$.

14. Huitle C.A.M., Rodrigo M.A., and Scialdone O. 2018. Electrochemical water and wastewater treatment. Cambridge, Elsevie.

15. Ippolito J.A., Barbarick K.A., and Elliott H.A. 2011. Drinking water treatment residuals: A review of recent uses. Journal of Environmental Quality, 40 (1), $1-12$.

16. Mortula M., Bard S.M., Walsh M.E., and Gagnon G.A. 2009. Aluminum toxicity and ecological risk assessment of dried alum residual into surface water. Journal of Civil Engineering, 36, 127-136.

17. Primadipta I.W., and Titah H.S. 2017. Bioremediation of alum sludge using Aspergillus niger with adding sawdust as bulking agent. Jurnal Teknik ITS, 6 (1), 95-99. (In Indonesian). 
18. Selintung M. and Azikin. 2012. Handling of sludge from Somba Opu water treatment plant. Science \& Tecnology Universitas Hasanuddin, 5 (2), 1-11. (In Indonesian)

19. Selvakumar K.V., Badarinarayanan N.S., Umesh A., Ezhilkumar P., and Yuvanashree E. 2016. Acid dye degradation using electrochemical batch recirculation flow reactor. Journal of Chemical and Pharmaceutical Sciences, 9 (1), 308-312.

20. Sengupta A.K. 2002. Process for selective coagulant recovery from water treatment plant sludge. Pat. No US 6945047 B1.

21. Songa C., Chua C.J., Tanga Y., Zhanga J.L., Lib J.,
Zhanga J., Wang K., McDermidb S., and Kozakb P. 2008. Voltage jump during polarization of a PEM fuel cell operated at low relative humidities. Int. Journal Hydrogen Energy, 33.

22. Varcoe J.R., Atanassov P., Dekel D.R., Herring A.M., Nijmeijer K., Scott K., Xu T., and Zhuang L. 2014. Anion exchange membranes in electrochemical energy sytems. Energy Environment Science, 7: 3135-3191.

23. Widayatno T., Gupita L.T., Novitasari P., and Imaswati S. 2016. Silver recovery from wastewater of washing X-ray photos: electrochemical characterization. Simposium Nasional RAPI XV UMS. (In Indonesian) 